\title{
Observations on the behaviour of the dugong (Dugong dugon Müller, 1776) from waters of the Lease Islands, eastern Indonesia
}

\author{
H.H. de Iongh ${ }^{1}$, B. Bierhuizen ${ }^{2} \&$ B. van Orden ${ }^{2}$ \\ 'Centre of Environmental Science, Leiden University, P.O. Box 9518, 2300 RA Leiden, The Netherlands; \\ ${ }^{2}$ Institute for Systematics and Population Biology, P.O. Box 94766, 1090 GT Amsterdam, The Netherlands
}

Keywords: Dugong, behaviour, feeding ecology, cultivation grazing

\begin{abstract}
A small population of dugongs was discovered in coastal waters of the Lease islands in eastern Indonesia. Studies on behaviour and feeding ecology revealed information on the interaction with seagrass meadows, modes of surfacing and submergence times and behaviour in the presence of scuba divers. Regular concentrated feeding was observed in a grazing sward at a subtidal monospecific Halophila ovalis meadow, confirming earlier observations of regular recropping by dugongs of grazing swards, covered by monospecific Halodule uninervis, inside an intertidal multi-species meadow.
\end{abstract}

\section{Résumé}

Une petite population de dugongs a été découverte dans les eaux côtières des îles Lease (Indonésie Orientale). L'étude du comportement et de l'écologie de la nutrition a foumi des informations sur l'interaction avec les prairies de végétation submergée, sur les modalités de l'émersion, les périodes de submersion, aỉnsi que sur le comportement en présence de plongeurs à scuba. Dans un pâturage faisant partie d'une prairie subtidale monospécifique à Halophila ovalis on a pu observer une activité concentrée de nutrition, ce quil confirme des observations précédentes sur la réutilisation par les dugongs de pâturages monospécifiques à Halodule uninervis faisant partie d'une praírie intertidale multispécifique.

\section{Introduction}

Few scientific records are available on the abundance, distribution and behaviour of dugongs in Indonesia. Salm (in Nishiwaki \& Marsh, 1985) reported in 1984, that dugongs are scattered throughout Indonesia, usually in low numbers. Little is known of the populations other than that they occur around Kupang Bay (Timor), Arakan Reef (North Sulawesi), Togian Island - Teluk Tominy (Central Sulawesi) and other small bays and straits around Sulawesi, including the Spermonde Islands, South Kalimantan, and the BangkaBelitung Islands (Karimata Strait) (Allen et al,, 1976; Hendrokusomo et al., 1981). Towards the end of 1979 dugongs were apparently still fairly numerous around the Aru Islands, their last known area of abundance in Indonesia (Compost, 1980). De Iongh et al. (1995a) reported on a population of 22-37 dugongs in the Lease Islands, identified during aerial surveys and studied the feeding ecology of dugongs on an intertidal Halodule dominated meadow (De Iongh et al., 1995b).

With respect to the dugongs' feeding ecology, most of the tropical areas supporting the highest dugong densities have extensive inshore seagrass meadows of Halodule uninervis, Halophila ovalis, and Halophila ovata, species that are often found in low density stands (Lanyon, 1991). These and other species of seagrass eaten by dugongs generally occur in the intertidal and upper subtidal to a depth of $10 \mathrm{~m}$ below the lowwater mark (Heinsohn \& Birch, 1972). When dugongs feed on morphologically small-leafed seagrasses such as Halodule and Halophila, they uproot and consume the entire plant, including rhizomes and roots (Anderson \& Birtles, 1978). This method of feeding produces characteristic feeding tracks (Heinsohn et al., 1977).

Preen (1993) postulated that seasonal nutritional stress in subtropical areas and a response to 


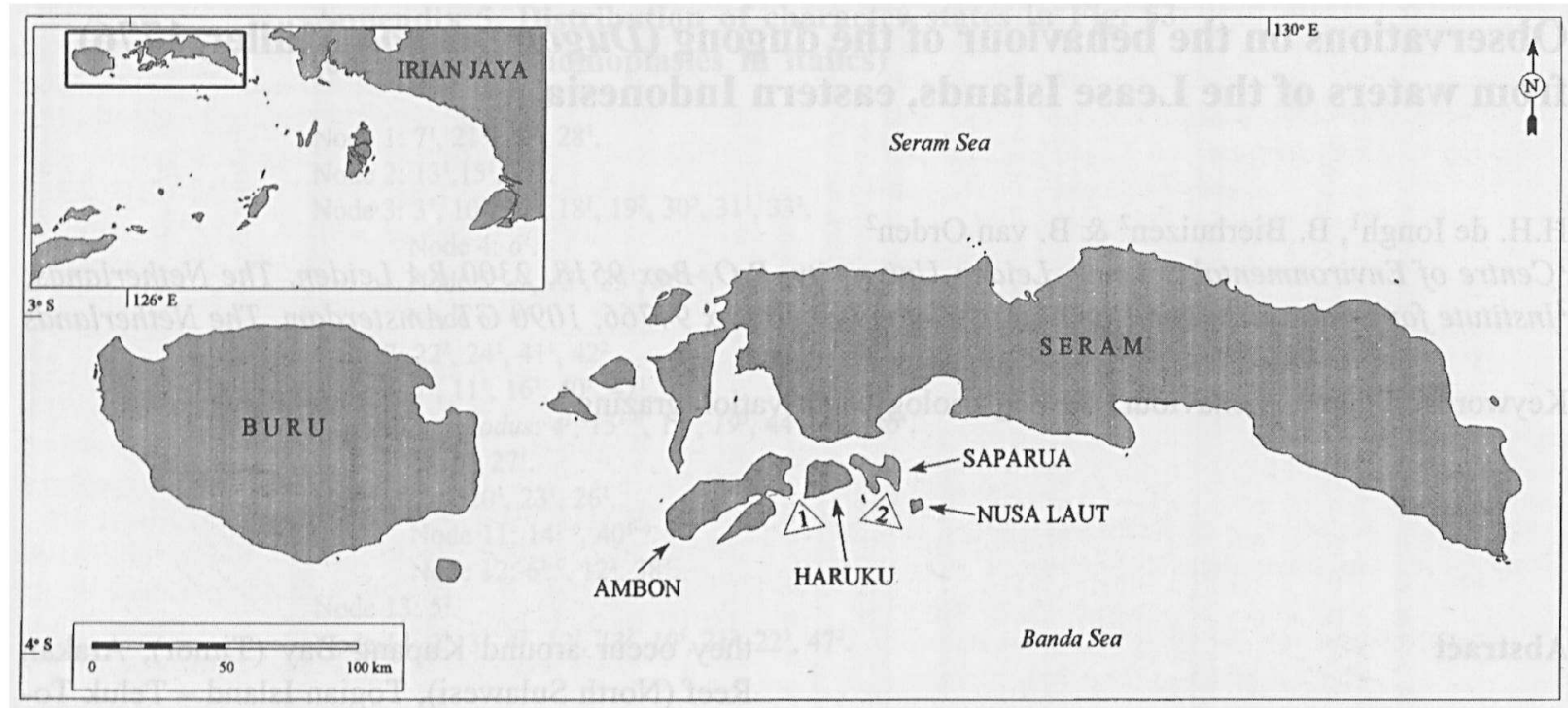

Fig. 1. Map of the central Moluccas, with the location of Haruku Strait (1) and Saparua Bay (2).

this stress by the phenomenon of "cultivation grazing" would be a major factor for the observed difference in herd size between subtropical and tropical areas. According to Preen $(1993,1995)$ "cultivation" grazing occurs when herds of dugongs forage intensively in an area, effecting a high level of seagrass removal over a large area. "Cultivation" grazing allows dugongs to improve the quality of their diet by one or more of the following: (1) maintaining the meadow at a younger, actively growing stage, so the seagrasses contain less fibre, (2) converting the meadow to a pioneer stage composed of preferred and nutritionally superior seagrasses, and (3) concentrating the regrowth vegetation into areas that can be efficiently cropped. He also stated that in tropical areas, the benefits of cultivation grazing may not be necessary or relevant, in which case there may be no pressure to feed in large herds.

De Iongh et al. (1995b) found quantitative evidence of a practice of regular recropping of grazing swards by small herds of dugongs in a tropical intertidal meadow. Regular recropping of fixed grazing swards was associated with "islands" of monospecific Halodule uninervis with a high density of feeding tracks, surrounded by an undisturbed mixed meadow of Cymodocea rotundata and Thalassia hemprichii. The present observations on behaviour and feeding ecology of the dugong population at the Lease Islands elaborate on the results of the studies of De Iongh et al. (1995a, 1995b). We also present qualitative observations on a pattern of regular recropping of a grazing sward by a small herd of dugongs in a subtidal monospecific Halophila ovalis meadow.

\section{Study site}

The study area covers Ambon and the Lease Islands (Haruku, Saparua, and Nusa Laut), located in the centre of the Moluccas Province in eastern Indonesia $\left(3^{\circ} 30^{\prime} \mathrm{S}, 128^{\circ} \mathrm{E}\right)$. The islands are bordered by the Banda Sea in the south and the Seram Sea in the north. The present study was made in the Haruku Strait between Ambon and Haruku islands, and in Saparua Bay (Fig. 1).

The islands are characterized by a mountainous landscape with a shallow coastal shelf present along most of the shore of the islands. On the east coast of Ambon the widest shelf is found between the villages of Waai and Tulehu, $500 \mathrm{~m}$ wide at the maximum. The maximum depth of the Haruku Strait is approximately $120 \mathrm{~m}$, while the maximum depth of Saparua Bay is approximately $40 \mathrm{~m}$. These shelf areas are generally sandy, but locally muddy-silty sediment is deposited near estuaries. Seasonal rainfall, wave exposure and tidal fluctuations lead to a very dynamic coastline characterized by significant transport of sediments. The climate of Ambon is strongly influenced by the monsoon seasons. The rainy season occurs during the south-east monsoon, from May until September. The dry season occurs during the north-west monsoon, from October until April. Sand is transported along the coast 


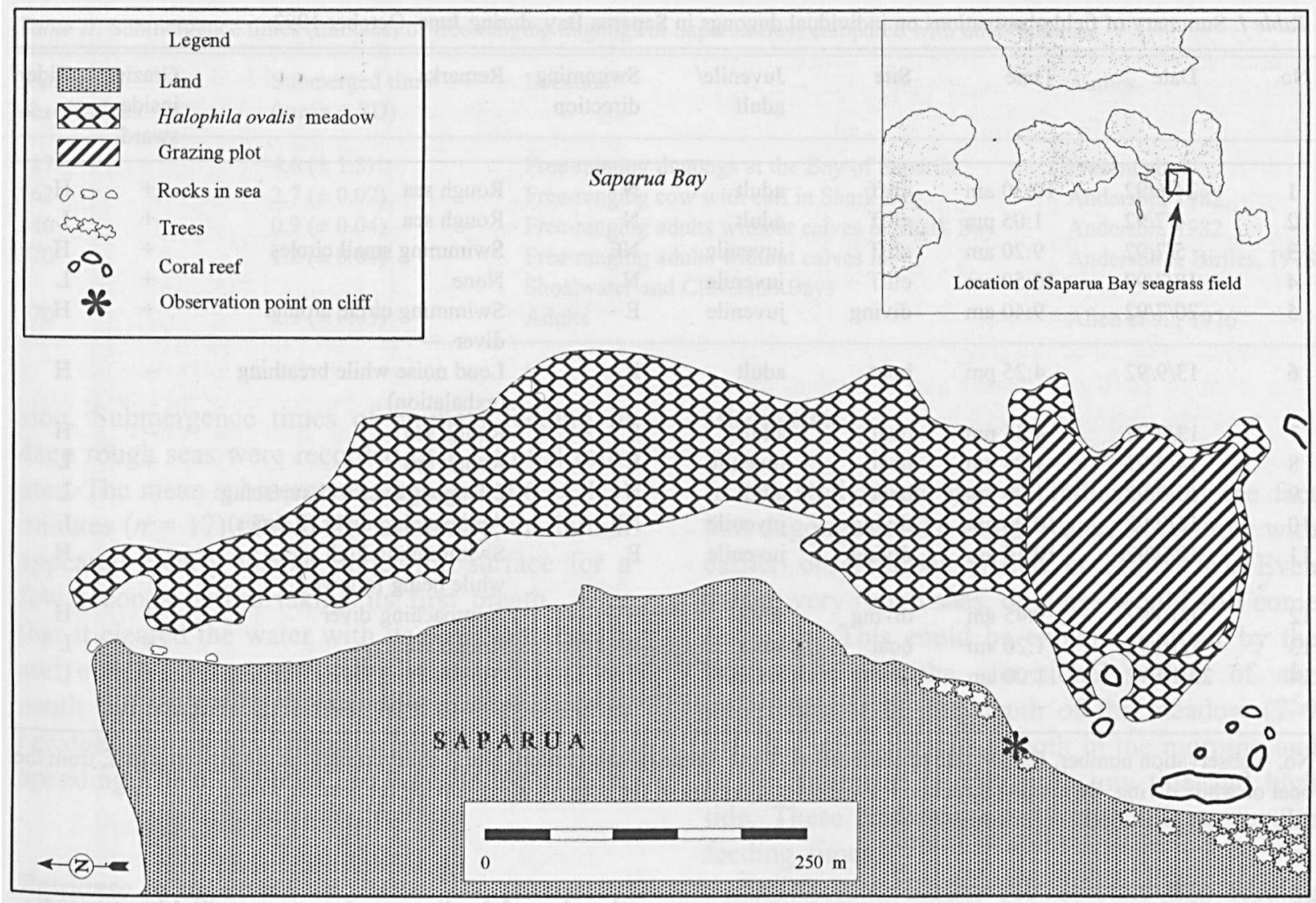

Fig. 2. Detailed map of the monospecific Halophila ovalis meadow in Saparua Bay and the location of the grazing sward.

from exposed to more sheltered locations by sea currents influenced by tidal patterns and the prevailing wind direction.

\section{Materials and methods}

During June-July and September-October 1992, free-ranging animals were observed from the top of a cliff in Saparua Bay. This site (Fig. 2), which is situated approximately $6 \mathrm{~m}$ above chart datum, provided an excellent view over the bay and a nearby monospecific seagrass bed of Halophila ovalis that covered approximately 2 ha at $7-10 \mathrm{~m}$ depth. During the study we measured turbidity with a standard Secchi disk; it ranged between $10-21 \mathrm{~m}$. When a dugong was spotted, notes were made on the time periods the animal spent at the water surface (surface time), and on the time periods the animal spent submerged between two successive surfacing intervals (submerged time). The number of inhalations was recorded as the number of times its nostrils were seen above the water surface. Additional observations were made from small boats on 24 June, 5 July, 20 July, 14 September, and 23 October 1992 and during scuba diving surveys on 5 July, 18 July, 13 September, and 1 October 1992. Feeding behaviour, surfacing and diving behaviour, as well as responses to approach by boats or divers were registered. Three modes of surfacing were described: rolling, sinking forward and sinking back (Anderson \& Birtles, 1978). The response of dugongs to approaches by one or more swimmers, or observers on a boat were described as: (a) no apparent response (continued routine activity), (b) curiosity, or (c) avoidance.

During each observation period, snorkling transects covering the seagrass bed (perpendicular to the coast and at 30 $\mathrm{m}$ intervals) were made to identify feeding track density in the meadow and a distinction was made between ungrazed and grazed patches.

\section{Results}

The results of the dugong observations in Saparua Bay are listed in Table I. The results of all field observations are summarized below.

Table II presents a summary of submergence times from the present study, compared with other authors. 
Table I. Summary of field observations on individual dugongs in Saparua Bay, during June-October 1992.

\begin{tabular}{|c|c|c|c|c|c|c|c|c|}
\hline No. & Date & Tìme & Site & $\begin{array}{l}\text { Juvenile/ } \\
\text { adult }\end{array}$ & $\begin{array}{l}\text { Swimming } \\
\text { direction }\end{array}$ & Remarks & $\begin{array}{l}\text { Grazing } \\
\text { inside } \\
\text { sward }\end{array}$ & Tide \\
\hline 1 & $24 / 6 / 92$ & $10: 30 \mathrm{am}$ & cliff & adult & $\mathbf{N}$ & Rough sea & + & $\mathbf{H}$ \\
\hline 2 & $4 / 7 / 92$ & $1: 05 \mathrm{pm}$ & cliff & adult & $\mathbf{N}$ & Rough sea & + & $\mathbf{L}$ \\
\hline 3 & $5 / 7 / 92$ & $9: 20 \mathrm{am}$ & cliff & juvenile & NE & Swimming small circles & + & $\mathbf{H}$ \\
\hline 4 & $18 / 7 / 92$ & $10: 50$ am & cliff & juvenile & $\mathbf{N}$ & None & + & $\mathbf{L}$ \\
\hline 5 & $20 / 7 / 92$ & $9: 40$ am & diving & juvenile & $\mathbf{E}$ & $\begin{array}{l}\text { Swimming circle around } \\
\text { diver }\end{array}$ & + & $\mathbf{H}$ \\
\hline 6 & $13 / 9 / 92$ & $4: 25 \mathrm{pm}$ & boat & adult & $\mathbf{E}$ & $\begin{array}{l}\text { Loud noise while breathing } \\
\text { (exhalation) }\end{array}$ & - & $\mathbf{H}$ \\
\hline 7 & $13 / 9 / 92$ & $4: 35 \mathrm{pm}$ & boat & adult & $\mathbf{E}$ & Rough sea & - & $\mathbf{H}$ \\
\hline 8 & $14 / 9 / 92$ & $1.05 \mathrm{pm}$ & boat & juvenile & $\mathbf{E}$ & Rough sea & + & $\mathrm{L}$ \\
\hline 9 & $15 / 9 / 92$ & $1: 00 \mathrm{pm}$ & boat & adult & $\mathbf{N}$ & 2 Dugongs/vertical surfacing & - & $\mathbf{L}$ \\
\hline 10 & $16 / 9 / 92$ & $10: 00 \mathrm{am}$ & diving & juvenile & $\mathrm{NE}$ & Approaching diver ( 2 times) & + & $\mathbf{L}$ \\
\hline 11 & 19/9/92 & $10: 15 \mathrm{am}$ & diving & juvenile & $\mathbf{E}$ & $\begin{array}{l}\text { Swimming in high speed } \\
\text { while being followed }\end{array}$ & + & $\mathbf{H}$ \\
\hline 12 & $1 / 10 / 92$ & $9: 45 \mathrm{am}$ & diving & adult & NW & Approaching diver & + & $\mathbf{H}$ \\
\hline 13 & $1 / 10 / 92$ & $1: 20 \mathrm{am}$ & boat & adult & $\mathbf{W}$ & Rough sea & + & $\mathbf{L}$ \\
\hline 14 & $23 / 10 / 92$ & $11: 00 \mathrm{am}$ & diving & juvenile & $\mathbf{S}$ & $\begin{array}{l}\text { Approaching diver ( } 3 \text { times)/ } \\
\text { grazing behaviour }\end{array}$ & + & $\mathbf{L}$ \\
\hline
\end{tabular}

No, $=$ observation number, Date $=$ date of observation, Time $=$ time of observation, Site $=$ observation took place from a cliff, from the boat or while diving, Swimming direction $=$ swimming direction of the dugong when leaving the feeding sward.

\section{Feeding behaviour}

During the research period fourteen free-ranging dugongs were observed, all occurring in the outer part of Saparua Bay. Observations of dugongs were done both in the morning and afternoon (Table I), not indicating regular feeding times. We observed that dugongs forage at depths down to $10 \mathrm{~m}$ in the bay. During several observations dugongs foraged within $50 \mathrm{~m}$ of a ten meter high cliff (which was used as an observation site). Dugongs were spotted during both at high and low tide (Table I). During a diving session we observed that three distinct feeding tracks were made by a dugong within a single dive. The dugong moved from one place to another in the seagrass meadow without surfacing. It grazed upon the vegetation, hovering above the substratum with only the rostrum bent down. Dugongs foraged also during periods of rough seas (Table I). During snorkling transects over the Paperu meadow, concentrated grazing in a monospecific Halophila ovalis meadow was observed in a distinct sward of approximately $260 \mathrm{~m}^{2}$ with a high density of feeding tracks, surrounded by an undisturbed seagrass bed at the southern part of the meadow (Table I and Fig. 2). During most consecutive observation periods, individual dugongs visited this feeding sward to forage. This regular pattern of visiting the sward was consistent during the study period (Table I).

Although local fishermen claimed that dugongs would forage deliberately on a lingulid brachiopod and Sipunculus sp. (identification Dr. K. den Hartog, National Museum of Natural History, Leiden) this was not confirmed by our own field observations.

\section{Surfacing and diving behaviour}

All three modes of surfacing have been observed. Rolling was the most frequently observed mode of submerging. Each time the back was clearly seen and sometimes even the tail cleared the water. The sinking forward mode was observed a few times "when the animals were seen swimming. Sinking back was seen on only one occa- 
Table II. Submergence times (minutes) of free-ranging dugongs in Saparua Bay, compared with other authors.

\begin{tabular}{llll}
\hline $\begin{array}{l}\text { Number of } \\
\text { observations }\end{array}$ & $\begin{array}{l}\text { Submerged time } \\
(\text { mean } \pm \text { SD) }\end{array}$ & Location & Author \\
\hline 17 & $4.6( \pm 1.3)$ & Free-ranging dugongs at the Bay of Saparua & Present study \\
162 & $2.7( \pm 0.07)$ & Free-ranging cow with calf in Shark Bay & Anderson, 1982 \\
346 & $0.9( \pm 0.04)$ & Free-ranging adults without calves in Shark Bay & Anderson, 1982 \\
370 & $1.2( \pm 0.04)$ & $\begin{array}{l}\text { Free-ranging adults without calves in } \\
\text { Shoalwater and Cleveland Bays }\end{array}$ & Anderson \& Birtles, 1978 \\
70 & $2.5( \pm 0.05)$ & Adults & Allen et al,, 1976 \\
\hline
\end{tabular}

sion. Submergence times of animals feeding in deep rough seas were recorded of 1.8 to $6.4 \mathrm{~min}$ utes. The mean submergence time was $4.6( \pm 1.3)$ minutes $(n=17)$ (Table II). Generally, an animal appeared clearly visible under the surface for a few seconds before taking its first breath. After that it cleared the water with its nostrils to breath and either submerged totally or stayed just beneath the surface to breath again. The dugongs breathed up to four times while at the surface, spending 3 to 62 seconds just beneath the surface.

\section{Response to approach}

Animals continued to feed when approached in a small outrigger boat (without an outboard engine). On one occasion, the approach of a large rowing boat caused a fright response. The animal surfaced vertically a few meters from the boat, facing the boat.

Most of the time, dugongs appeared to display curiosity towards divers. They either swam in circles around the divers or approached while swimming, at a distance of approximately three meters. Once a diver was able to approach an adult dugong at c. $1 \mathrm{~m}$ distance. On another occasion, an adult dugong of approximately $3 \mathrm{~m}$ in length approached the diver, who was lying at the bottom, swimming in a zigzag fashion. It swung around its long axis, holding its flippers wideopen and passed the diver, turned and passed again in the same way. Suddenly the dugong swam upwards to the sea surface. The animal rested just beneath the surface, turned again and swam in a straight line towards the diver, changing its course only at close range (c. $2 \mathrm{~m}$ distance).

\section{Discussion}

In our study there was no indication of the fact that dugongs dislike rough water, in contrast with earlier observations (Allen et al., 1976). Even during very rough seas, dugongs would still come to forage. This could be explained either by the importance of - the nutritional value of the seagrasses or by the depth of the meadow (7-9 $\mathrm{m})$. We spotted dugongs both in the morning and in the afternoon, during both low tide and high tide. These observations do not indicate regular feeding times.

Anderson \& Birtles (1978) state that feeding tracks are only found in Zostera and Halophila and thought that each trench represented the effort of a single dive. During our study this statement was not confirmed; a dugong was observed feeding, producing multiple feeding tracks. The dugong's behaviour may be adjusted in order to minimize effort for a maximum of energy intake (De Iongh et al., 1995b). Multiple feeding tracks during one dive support this assumption.

In our study the mean submergence time of the dugong is 4.6 minutes. This is longer than the time lengths found by Allen et al. (1976), Anderson (1982), and Anderson \& Birtles (1978), who observed mean submergence times of 2.5 , 2.7, and 1.2 minutes, respectively (Table II). Those studies were done in waters up to 3 meters of depth. Our studies were carried out in seagrass beds up to $9 \mathrm{~m}$ depth. This suggests that the submergence time may be correlated with the depth of the bed, coinciding with Anderson (1982) who concluded that the interval between appearances at the surface varies with locality (habitat), foraging mode and foraging species, activity, and reproductive status. His data, obtained from waters 
of varying depths, suggest a trend for dugongs to remain submerged longer in deeper water. In the present study, the time spent at the surface was minimum 3 seconds for one breath, which agrees with Anderson \& Birtles (1978).

With respect to the feeding ecology of the dugong, some of our observations do not correspond with the findings of other authors. Anderson (1981) and Anderson \& Birtles (1978), for example, report that dugongs forage at depths of 3 to $4 \mathrm{~m}$ in both sublittoral and intertidal areas. Most of the feeding tracks we observed at the seagrass bed in Saparua Bay were located at a greater depth (7-9 m). Marsh et al. (1994) and Marsh (1993) reported on the importance of deepwater seagrass meadows to dugongs and found evidence of dugong feeding up to $40 \mathrm{~m}$ depth. Favoured feeding areas appeared to be characterized by relatively sparse seagrass and ready access to deeper water. The regular recropping by dugongs of restricted grazing swards in a monospecific Halophila ovalis meadow may indicate a pattern of cultivation grazing as described by Preen (1993, 1995) for dugongs in Moreton Bay, but more research data are needed to confirm this.

\section{Acknowledgements}

We thank Dr. H. Blaauw and Ir. B. Romijn of the Foundation AID Environment in Amsterdam for their help in fieldwork in Nang Embayment, as well as Mr. D. Norimarna, Director of the Environmental Studies Centre of Pattimura University at Ambon and Dr. K. Moosa of the National Research Centre for Oceanology in Jakarta for their continued support to our study. Furthermore, we are grateful to Prof. Dr. P.H. Nienhuis of the Department of Environmental Studies, University of Nijmegen and of the Netherlands Institute of Ecology, Nieuwersluis, and Prof. Dr. H.H.T. Prins of the Department of Terrestrial Ecology and Nature Conservation of the Agricultural University Wageningen, and Prof. Dr. C. den Hartog of the Laboratory of Aquatic Ecology, Catholic University of Nijmegen, for correcting the manuscript. We also thank Dr. Lynn Lefebvre, Sirenia Project Leader of the National Biological Survey in Gainesville (U.S.A.), and Prof. Dr. Helene Marsh of James Cook University, who introduced us into the remarkable world of Sirenia ecology. Dr. Paul Erftemeyer of the Centre for Estuarine and Coastal Research at Yerseke and Mark van der Wal of the Foundation AID Environment gave us logistical, moral, and scientific support throughout our study. A special word of thanks goes to Quinten Waisfisz, who assisted us during fieldwork in Saparua Bay. We are likewise grateful to Sjoukje Rienks who assisted with typewriting and with the layout of the manuscript. Last but not least, we would like to express our gratitude to Simon Simatauw and Sam Hallatu, who assisted us throughout this study, Bos Nanni, who gave technical support, and the Village Head and villagers of Waai, who provided us with their warm hospitality.

\section{References}

Allen, J.F , M.M. Lepes, I.T. Budiarso, D. Sumitro \& D. Hammond, 1976. Some observations on the biology of the dugong (Dugong dugon) from the waters of south Sulawesi. Aquatic Mammals, 4 (2): 33-48.

Anderson, P.K., 1981. The behaviour of the dugong (Dugong dugon) in relation to conservation and management. Bull. mar. Sci., 31 (3): 640-647.

Anderson, P.K., 1982. Studies of dugongs at Shark Bay, Western Australia, I. Analysis of population size, composition, dispersion and habitat use on the basis of aerial surveys. Aust. Wildl. Res, 9: 69-84.

Anderson, P.K. \& A. Birtles, 1978. Behaviour and ecology of the dugong, Dugong dugon (Sirenia): observations in Shoalwater and Cleveland Bays, Queensland. Aust. Wildl. Res., 5: 1-23.

Compost, A, 1980. Pilot survey of the exploitation of dugongs and sea turtles in the Aru islands. Yayasan Indonesia Hijau: 1-62.

De Iongh, H.H, B. Bierhuizen \& B. van Orden, 1995a. Aerial survey of the dugong (Dugong dugon Müller 1776) in coastal waters of the Lease Islands, East Indonesia. Aust. J. mar. freshwat. Res., 46: 61-75.

De Iongh, H.H., B. Wenno \& E. Meelis, 1995b. Seagrass distribution and seasonal biomass changes in relation to dugong grazing in the Moluccas, Indonesia. Aquatic Botany, 50: 1-19.

Heinsohn, G.E. \& W.R. Birch, 1972. Food and feeding habits of the dugong, Dugong dugon (Erxleben), in northern Queensland, Australia. Mammalia, 36 (3): 414-422.

Heinsohn, G.E., J. Wake, H. Marsh \& A.V. Spain, 1977. The dugong (Dugong dugon Müller) in the seagrass system. Aquaculture, 12: 235-248.

Hendrokusumo, S., D. Sumitro, Tas'an, 1979. The distribution of the dugong in Indonesian waters. In: $\mathrm{H}$. Marsh (ed.), The Dugong. Proceedings of a Seminar/Workshop held at the James Cook University of North Queensland, 8-13 May: 10-18.

Lanyon, J., 1991. The nutritional ecology of the Dugong (Dugong dugon) in tropical North Queensland: 1-327 (Ph.D. thesis, Department of Ecology and Evolutionary Biology, Monash Univ., Victoria, Australia).

Marsh, H., 1993. Dugongs and seagrass in Australia: the big picture. Abstracts of 6th International Theriological Congress: 196. (Univ. of New South Wales, Sydney, July 1993).

Marsh, H., R.I.T. Prince, W.K. Saalfeld \& R. Shepherd, 
1994. Distribution and abundance of dugongs in Shark Bay, Western Australia. Austr. Wildl. Res., 21: 56-74.

Nishiwaki, M. \& H. Marsh, 1985. The dugong, Dugong dugon (Müller 1776). In: S. H. Rídgway \& $R$. Harrison (eds.), Handbook of marine mammals, 3: 1-31 (Academic Press, London).

Preen, A., 1993. Interactions between dugongs and seagrasses in a subtropical environment: 1-392 (Ph.D. thesis,
Dept. of Zoology, James Cook Univ., North Queensland, Australia).

Preen, A., 1995. Impacts of dugong foraging on seagrass habitats: observational and experimental evidence for cultivation grazing. Mar. Ecol. Progr. Ser., 124: 201-213.

Accepted: 18 June 1997 